\title{
The Tikiusaaq carbonatite: a new Mesozoic intrusive complex in southern West Greenland
}

\author{
Agnete Steenfelt, Julie A. Hollis and Karsten Secher
}

Ultrabasic alkaline magmatic rocks are products of melts generated deep within or at the base of the lithospheric mantle. The magmas may reach the surface to form lavas and pyroclastic deposits; alternatively they crystallise at depth to form dykes or central complexes. The rocks are chemically distinct and may contain high concentrations of economically interesting minerals and chemical elements, such as diamonds, niobium, tantalum, rare earth elements, phosphorus, iron, uranium, thorium, and zirconium. Ultrabasic alkaline rocks are known from several provinces in Greenland, but extrusive facies have only been preserved at a few places; e.g. at Qassiarsuk in South Greenland where pyroclastic rocks occur, and in the Maniitsoq region, where a small volcanic breccia ('Fossilik') contains fragments of Palaeozoic limestone. Ultramafic lamprophyre and kimberlite are mainly emplaced as dykes, whereas carbonatite forms large intrusive bodies as well as dykes. The ultrabasic alkaline magmas that have been emplaced at certain times during the geological evolution of Greenland can be related to major episodes of continental break-up (Larsen \& Rex 1992). The oldest are Archaean and the youngest dated so far are Palaeogene. Figure 1 shows the distribution of known ultrabasic alkaline rocks in West Greenland.

The large and well-exposed bodies of alkaline rocks and carbonatites in the Gardar Province were discovered already in the early 1800s (Ussing 1912), while less conspicuous bodies were discovered much later during geological mapping and mineral exploration. Many alkaline rock bodies, particularly dykes, are difficult to identify in the field because they weather more extensively than the country rock gneisses and form vegetated depressions in the landscape. However, their distinct chemistry and mineralogy render alkaline rocks identifiable in geochemical and geophysical survey data. Thus, the Sarfartôq carbonatite complex was discovered during regional airborne gamma-spectrometric surveying owing to its elevated uranium and thorium contents (Secher 1986).

The use of kimberlite indicator minerals has led to the discovery of alkaline rocks such as kimberlites and ultramafic lamprophyres that carry fragments of deep lithospheric mantle.

Fig. 1. Occurrences of lamprophyre, kimberlite and carbonatite in the southern part of West Greenland.

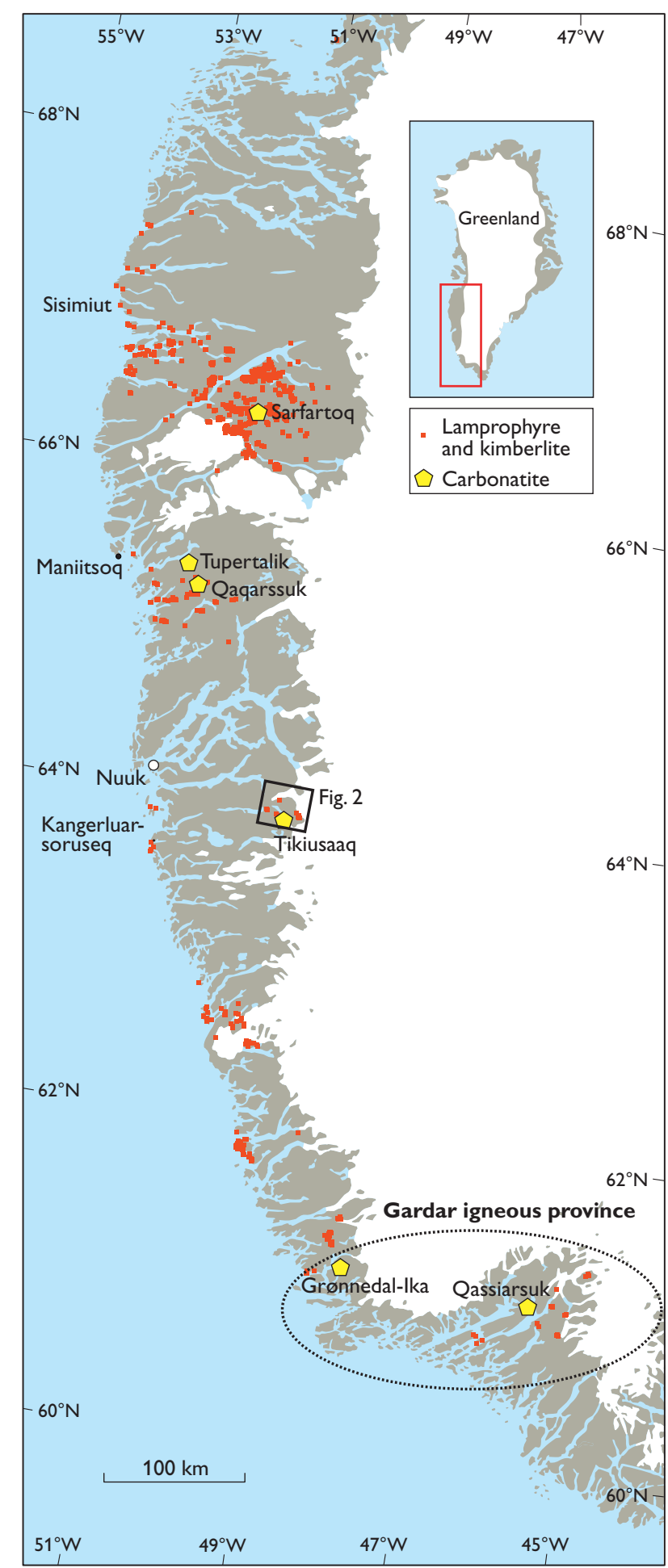




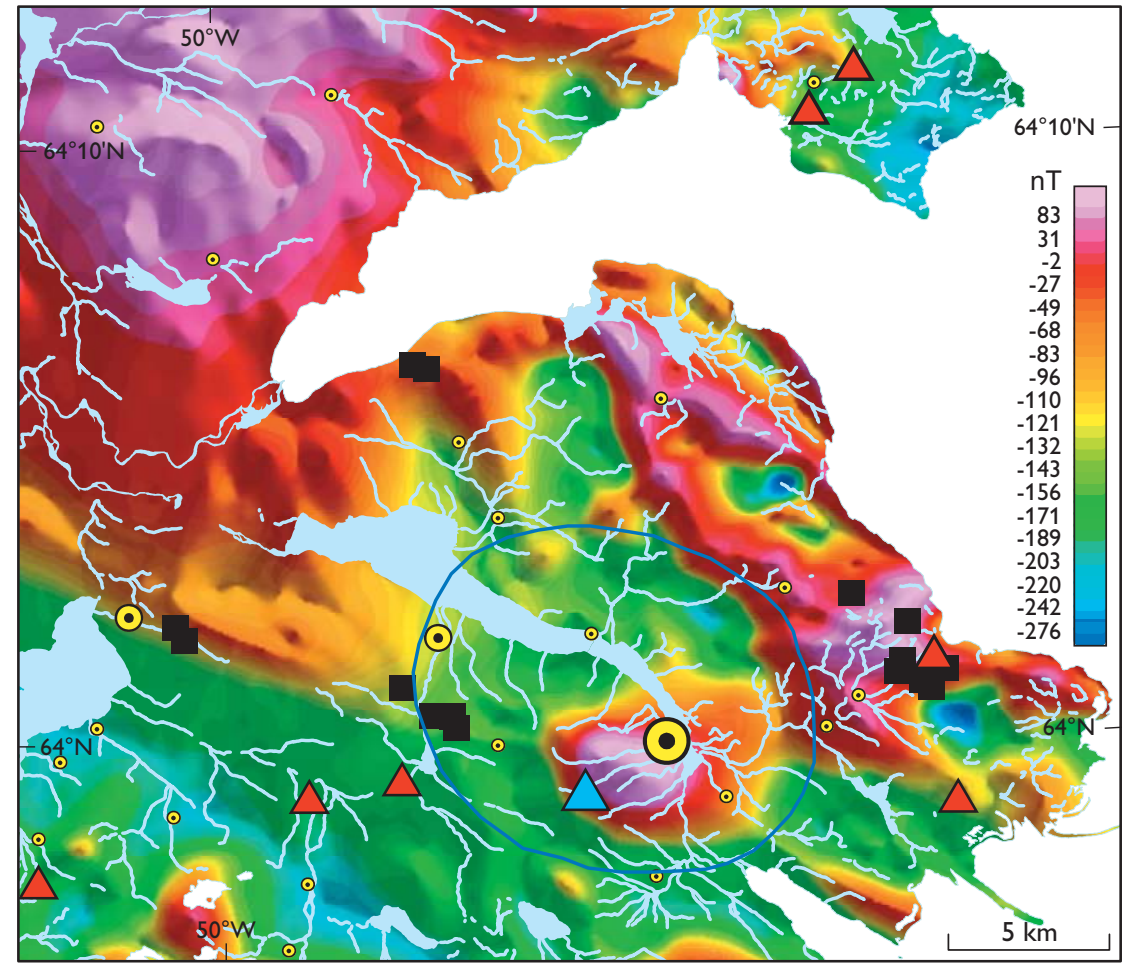

Outline of carbonatite complex

Carbonatite core locality

Lamprophyre dyke or boulder

Till or stream sediment sample with mantle-derived garnet

Such rocks may also contain diamonds. Kimberlite indicator minerals are high-pressure varieties of minerals, such as garnet, clinopyroxene, chromite and ilmenite that were formed in the lithospheric mantle. Exploration companies have processed thousands of till samples from southern West Greenland for kimberlite indicator minerals and found many new dykes.

\section{A new carbonatite complex and associated lamprophyre dykes}

A new carbonatite complex, named Tikiusaaq, was discovered in 2005 approximately $100 \mathrm{~km}$ east of Nuuk, as a result of a field-check of a combined stream sediment geochemical and aeromagnetic anomaly (Figs 1,2). A stream sediment sample collected during the geochemical mapping of West Greenland (Steenfelt 2001) had a chemical composition that strongly indicated the presence of carbonatitic rocks similar to those at Sarfartoq (Secher \& Larsen 1980) and Qaqarssuk (Knudsen 1991). A small-sized but strong magnetic anomaly (Fig. 2) displayed by the aeromagnetic map of West Greenland (see e.g. Rasmussen 2002) upstream of the anomalous
$\mathrm{P}_{2} \mathrm{O}_{5} \%$ in stream sediment

$\odot \quad 0.02-0.36$

- $0.37-1.17$

(-) $1.18-3.95$
Fig. 2. Close-up of the area, where the new carbonatite was found. The map shows a shaded image of the total magnetic field with large lakes and streams (light blue), and the Inland Ice (white) superposed on the image. Symbols illustrate the concentration of phosphorus $\left(\mathrm{P}_{2} \mathrm{O}_{5}\right)$ in stream sediment and localities where mantle-derived garnet grains have been identified in till or stream sediment. The occurrence of a distinct positive magnetic ano-maly in combination with anomalous stream sediment composition downstream was a strong indication of the presence of alkaline or carbonatitic rocks. The fieldwork confirmed solid carbonatite sheets (dark blue triangle), lamprophyre dykes (black squares), and an area (ringed) of fracturing and veining related to the intrusion of the carbonatite magma. sample also favoured the presence of carbonatite, as large magnetite accumulations are characteristic features of carbonatite complexes. The field work confirmed the presence of the new carbonatite complex. The complex appears to be centred at the position $64^{\circ} \mathrm{N}, 49^{\circ} 46^{\prime} \mathrm{W}$, where in situ massive carbonatite was found in the walls of a creek cutting through a gentle slope covered by gravel and vegetation.

The preliminary field observations have determined that the emplacement of the carbonatite has affected an area of more than $100 \mathrm{~km}^{2}$ within highly metamorphosed and strongly deformed Archaean basement comprising granite, dioritic and tonalitic orthogneiss, amphibolite, and anorthosite. Centrally in the area (Fig. 2), closely spaced, nearvertical massive carbonatite sheets are up to several metres wide (Fig. 3). In their surroundings, the host rocks have been chemically altered (fenitised), and further away the host rocks are fractured and contain numerous small veins $(<1 \mathrm{~mm}$ to $20 \mathrm{~cm}$ ) of carbonatite. The brittle fracturing together with the observation of carbonate-rich breccia indicates that the intrusion was explosive. The dimensions and internal structure of the core zone have not yet been established. However, by analogy with other carbonatite complexes in West Green- 


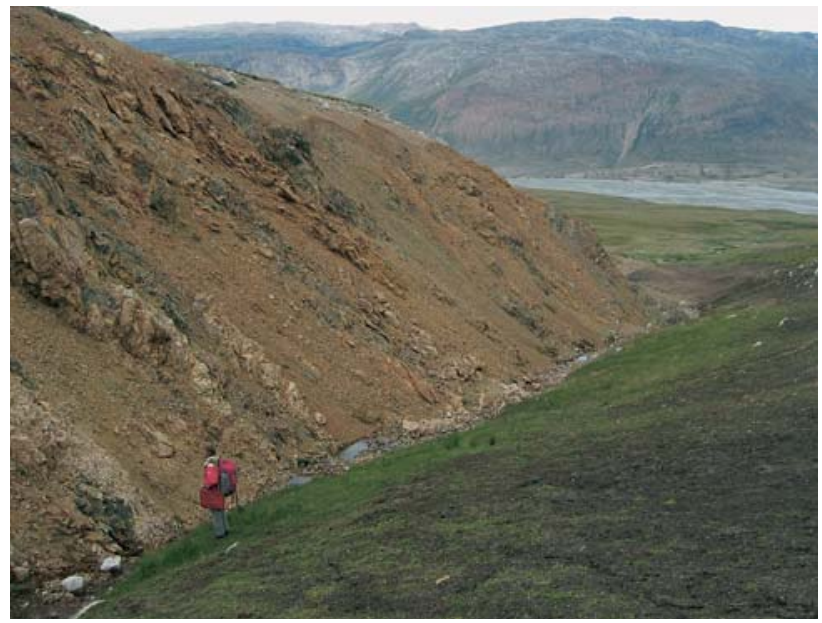

Fig. 3. View northwards along creek with exposed near-vertical sheets of carbonatite emplaced into mafic host rock. Intense fracturing with yellow-brown coating of fracture surfaces characterises both the core zone and its surroundings.

land, it is expected that the core zone is in the order of 1-2 $\mathrm{km}$ wide.

In addition to the main carbonatite body, many boulders and a few outcropping ultramafic alkaline dykes were discovered in the area north and north-east of the Tikiusaaq carbonatite, and these are the likely source of the kimberlite indicator minerals previously recorded in till samples from this area (Fig. 2). The observed dykes were only exposed over a few metres, are between 1 and $4 \mathrm{~m}$ wide, and have strikes that vary between E-W and NE-SW.

\section{Mineralogy, chemistry and age}

\section{Carbonatite}

Preliminary field work has identified at least two carbonatite varieties, one pale, creamy white in colour and one brownish grey (Fig. 4). The white variety is calcite carbonatite containing disseminated grains or bands of pale green mica, magnetite and apatite. Barite and monazite have been found in small amounts. The grey variety is dolomite carbonatite with occasional tiny brown spots suggesting an ankeritic component.

Boulders of carbonate-rich breccia have abundant xenoliths of the host orthogneiss and garnet-clinopyroxene aggregates (up to $1 \mathrm{~cm}$ diameter), along with xenocrysts of phlogopite, olivine, and rare garnet. The matrix of the breccia is similar to that of in situ brown-weathering thin carbonatite dykes within the complex; hence it seems likely that the boulders are derived from a certain phase within the carbonatite.

A preliminary age determination of $158 \pm 2$ Ma suggests that the carbonatite is Late Jurassic. This age was determined by means of $\mathrm{U}-\mathrm{Pb}$ isotope analysis by Laser Ablation-Sector

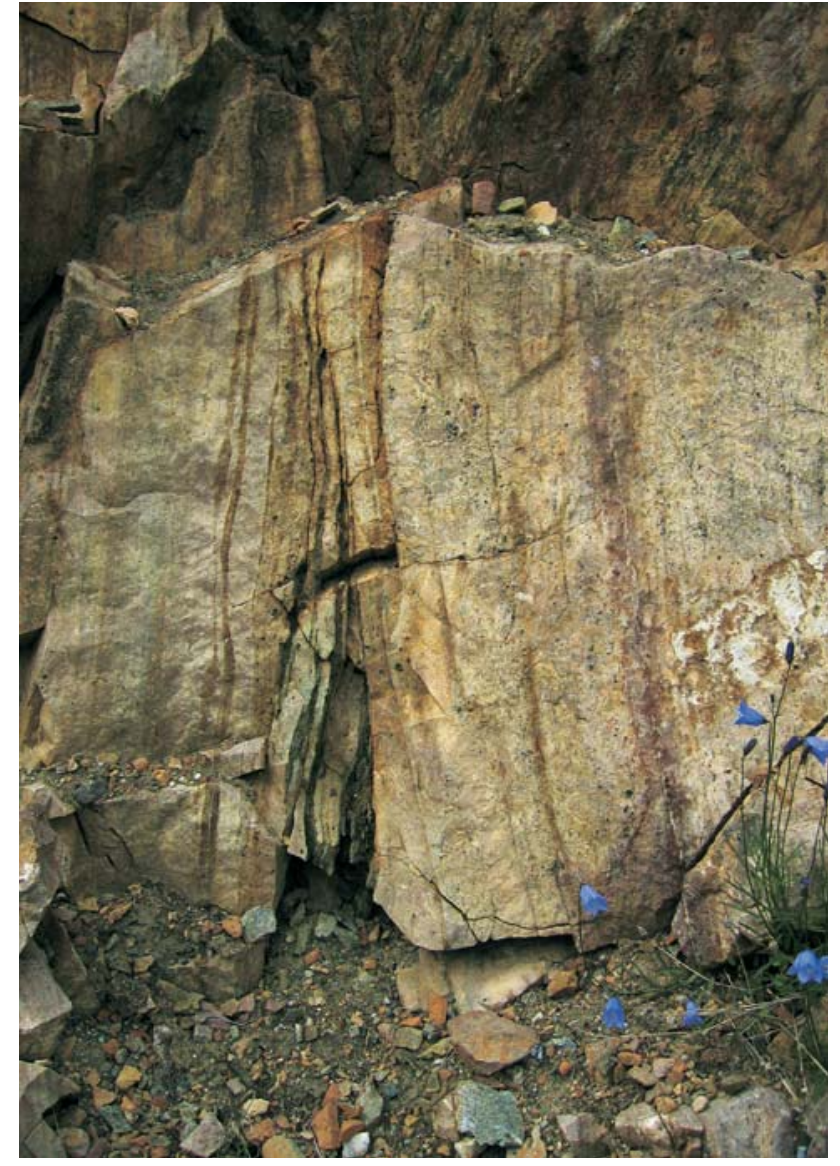

Fig. 4. Cream-coloured banded calcitic carbonatite with veins of brown ankeritic carbonatite. The faint banding is caused by variable amounts of disseminated green mica and greyish green apatite.

Field-Inductively Coupled Plasma Mass Spectrometry of a zircon crystal from the breccia described above (see also Frei et al. 2006, this volume). The age makes the new carbonatite near-coeval with the Qaqarssuk carbonatite (173 Ma, Larsen \& Rex 1992). Further age determinations based on Rb-Sr isotope chemistry of mica grains from the carbonatite and from one of the lamprophyre dykes are underway.

\section{Ultramafic dykes}

Boulders and in situ dykes of ultramafic lamprophyres vary in appearance and mineralogy. One widespread type has an olivine-rich groundmass and variable amounts of phlogopite crystals, 2 to $20 \mathrm{~mm}$ in size, together with phenocrysts of olivine and magnetite (Fig. 5). Other occurrences have variable additional carbonate and mica contents in the groundmass. The rocks are possible kimberlites. Mantle-derived xenocrysts or xenoliths were not observed macroscopically with certainty, but the presence of mantle-derived minerals will be further tested by means of microscopy and processing of large samples. 


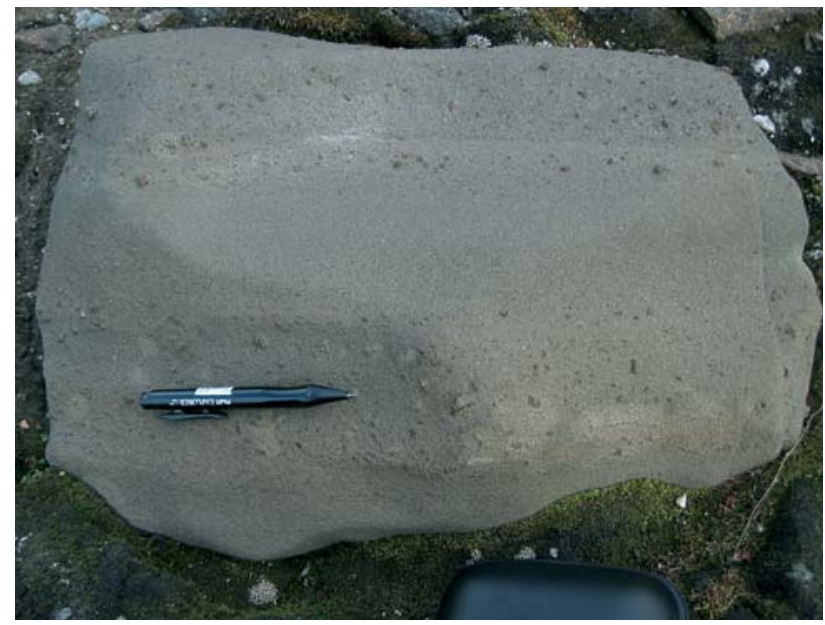

Fig. 5. Boulder of ultramafic lamprophyre with olivine rich groundmass and phenocrysts of olivine and magnetite.

\section{Significance of discovery}

The discovery of the carbonatite in the Nuuk region was made in a part of West Greenland where alkaline rocks have not hitherto been recorded. The nearest other occurrences are ultramafic lamprophyre dykes recorded at Kangerluarsoruseq (formerly Færingehavn) on the coast some $100 \mathrm{~km}$ westsouth-west of the Tikiusaaq carbonatite, and the southernmost of the Maniitsoq kimberlites at least $150 \mathrm{~km}$ to the north-west. The ultramafic lamprophyre dykes at Kangerluarsoruseq yielded ages of $175 \pm 7,185 \pm 7$ and $196 \pm 8 \mathrm{Ma}(\mathrm{K}-$ Ar dating; Larsen \& Rex 1992), and are thus likely to be part of related intrusive events.

Carbonatites and kimberlites commonly intrude into weakened zones through the crust, such as large rifts and sutures between former continents. Thus, the 560 to $580 \mathrm{Ma}$ old Sarfartôq carbonatite and associated kimberlites occupy the northern margin of the stable Archaean block, and the $c$. 1300 to 1100 Ma old Gardar magmas, including the carbonatite within the Grønnedal-Ika alkaline complex, were emplaced in major rift zones close to the southern margin of the Archaean block.
The Tikiusaaq carbonatite and the nearby lamprophyre dykes, together with the lamprophyre dykes at Kangerluarsoruseq are situated near the proposed collision zone between the northern margin of an Archaean continent (the Tasiusarsuaq terrane) and another continent (Friend et al. 1988; McGregor et al. 1991). This suggests that the newly discovered occurrences of alkaline rocks could be the eastern part of a tract extending along the continent margin, and that more alkaline dykes could be found in this tract. Furthermore, the existence of ultramafic lamprophyres in this area opens a possibility of obtaining xenocrystic material from a part of the mantle below Greenland that is presently unknown. Finally, the discovery of the carbonatite and ultramafic lamprophyres adds to the mineral potential of this part of Greenland.

\section{References}

Frei, D., Hollis, J.A., Gerdes, A., Karlsson, C., Vasquez, P., Franz, G., Harlov, D., Johansson, L. \& Knudsen, C. 2006: Advanced in situ trace element and geochronological microanalysis of geomaterials by laser ablation techniques. Geological Survey of Denmark and Greenland Bulletin 10, 25-28.

Friend, C.R.L., Nutman, A.P. \& McGregor, V.R. 1988: Late Archaean terrane accretion in the Godthåb region, southern West Greenland. Nature 335, 535-538.

Knudsen, C. 1991: Petrology, geochemistry and economic geology of the Qaqarssuk carbonatite complex, southern West Greenland. Monograph Series of Mineral Deposits 29, $110 \mathrm{pp}$.

Larsen, L.M. \& Rex, D.C. 1992: A review of the 2500 Ma span of alkalineultramafic, potassic and carbonatitic magmatism in West Greenland. Lithos 28, 367-402.

McGregor, V.R., Friend, C.R.L. \& Nutman, A.P. 1991: The late Archaean mobile belt through Godthåbsfjord, southern West Greenland: a continent-continent collision zone? Bulletin of the Geological Society of Denmark 39, 179-197.

Rasmussen, T.M. 2002: Aeromagnetic survey in central West Greenland: project Aeromag 2001. Geology of Greenland Survey Bulletin 191, $67-72$.

Secher, K. \& Larsen, L.M. 1980: Geology and mineralogy of the Sarfartôq carbonatite complex, southern West Greenland. Lithos 13, 199-212.

Secher, K. 1986: Exploration of the Sarfartôq carbonatite complex, southern West Greenland. Rapport Grønlands Geologiske Undersøgelse 128, 89-101.

Steenfelt, A. 2001: Geochemical atlas of Greenland - West and South Greenland. Danmarks og Grønlands Geologiske Undersøgelse Rapport 2001/46, 39 pp. (1 CD-ROM).

Ussing, N.V. 1912: The geology of the country around Julianehaab, Greenland. Meddelelser om Grønland 38, 1-426. 